\title{
Accent stigmatization as a moderator of the relationship between perceived L2 proficiency and L2 use anxiety
}

\section{Vincze, Laszlo}

2017-03

Vincze , L \& Maclntyre , P 2017 , ' Accent stigmatization as a moderator of the relationship between perceived L2 proficiency and L2 use anxiety ' , Applied Linguistics Review , vol. 8 , no. 1 , pp. 61-78 . https://doi.org/10.1515/applirev-2015-2004

http://hdl.handle.net/10138/233359

https://doi.org/10.1515/applirev-2015-2004

publishedVersion

Downloaded from Helda, University of Helsinki institutional repository.

This is an electronic reprint of the original article.

This reprint may differ from the original in pagination and typographic detail.

Please cite the original version. 


\title{
Laszlo Vincze* and Peter Maclntyre Accent stigmatization as a moderator of the relationship between perceived L2 proficiency and L2 use anxiety
}

\author{
DOI 10.1515/applirev-2015-2004
}

\begin{abstract}
By integrating the social context model of L2 acquisition with the pyramid model of willingness to communicate in L2, this study examined aspects of the psychological process underlying willingness to communicate (WTC) in Slovak among young Hungarian speakers in Southern Slovakia. The data was collected among Hungarian-speaking secondary school students $(N=310)$. The results indicated that frequent and pleasant contact with Slovak speakers was related to higher proficiency in Slovak and lower anxiety to use Slovak, and these increased the willingness to communicate in Slovak. However, it was also demonstrated that accent stigmatization moderated the relationship between perceived L2 proficiency and L2 use anxiety. Anxiety was more closely related to proficiency among those who perceived less accent stigmatization than among those who perceived more stigma because of their Hungarian accent. The theoretical implications of these findings for the role of the intergroup context in developing accent stigmatization, and the link between accent stigmatization, L2 use anxiety and willingness to communicate in the majority language are discussed.
\end{abstract}

Keywords: L2 use anxiety, accent stigmatization, willingness to communicate, Hungarian in Slovakia

\section{Introduction}

L2 use anxiety is usually defined as "the worry and negative emotional reaction aroused when learning or using a second language” (MacIntyre 1999: 27), and it has been one of the most widely studied concepts related to second language learning in the last decades (for recent reviews, see Horwitz 2010; Gregersen and MacIntyre 2014). Anxiety can hinder various aspects of language progress and make individuals unwilling to communicate in the L2.

\footnotetext{
*Corresponding author: Laszlo Vincze, Swedish School of Social Science, University of Helsinki, Snellmaninkatu 12, Helsinki 00014, Finland, E-mail: laszlo.vincze@helsinki.fi Peter MacIntyre, Department of Psychology, Cape Breton University, Sydney, Nova Scotia, Canada
} 
The list of potential sources of L2 use anxiety has many diverse entries. Generally, anxiety has been found to "arise from past negative experiences" (Sampasivam and Clément 2014: 25) and it is related to the educational context such as teaching practices and classroom climate (e. g. Horwitz 2001). Language anxiety has been shown to correlate with learner factors such as personality traits (Dewaele 2002, 2013), emotional intelligence (Dewaele et al. 2008) and inclination to perfectionism (Gregersen and Horwitz 2002). Additionally and importantly, research suggests that in bilingual settings L2 use anxiety may largely depend also on the social context (Sampasivam and Clément 2014). Indeed, as Gardner and MacIntyre note, in settings where the language groups live side by side "social milieu enhances correlates of language anxiety and produces a more complex construct combining language anxiety, self-perceptions of proficiency and attitudinal/motivational components" (Gardner and MacIntyre 1993: 7). Although there is a considerable body of research about the effects of the educational context and personality on anxiety (see Horwitz 2010), relatively little effort has been made to explore the role of social context in developing anxiety.

Focusing on a unique bilingual setting, the present study aims to extend the understanding of the development of L2 use anxiety by examining more closely the social context from which it comes. Specifically, we examine how contact between the language groups and perceived L2 proficiency may affect L2 use anxiety, leading to variations in willingness to communicate (WTC) in L2. In addition, our focus also will be on a specific aspect of the context: the experience of speaking an L2 with non-native accent. More particularly, we address how feedback from L2 speakers about non-native accent can moderate the relationship between perceived L2 proficiency and L2 use anxiety, and contribute to greater anxiety and less willingness to communicate in L2.

\subsection{Speaking an L2 with a non-native accent}

In second language learning situations, it is common that the intonation and the phonological structure of the first language exert an impact on the pronunciation in the second language. A native-like accent might be seen as desirable but is very difficult, almost impossible, to reach even after many years of language learning (Derwing and Munro 2009; Gluszek et al. 2011). Indeed, those who speak a second language fluently very often do it with a non-native accent.

Although there may be individual differences in the degree of accent strength, a non-native accent is usually recognized immediately by a native speaker. In cases where accent signals a local variety or a dialect of a language, 
individuals who possess both the variety and the standard form of the language can change their accent to manage social distance between themselves and their interlocutors, a process of converging to or diverging from their speech (e. g. Soliz and Giles 2014).

Yet, accented speech often occurs against the speaker's intention, and it can lead to adverse psychological consequences (Gluszek and Dovidio 2010a, 2010b).

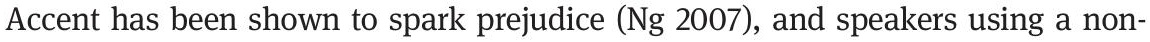
native accent often have to cope with negative attitudes, stigmatization and discrimination of their interlocutors (Derwing 2003; Gluszek and Dovidio 2010b). Decades of research applying matched guise technique (Lambert 1967) summarized in a recent meta-analysis, indicates that listeners generally evaluate a nonnative accent less favourably than standard accents (Fuertes et al. 2012; see also Derwing 2003; Munro 2003; Derwing and Munro 2009).

However, communication is an interactive process, and attitudinal outcomes with the listener cannot be regarded as an endpoint. As recent studies by Gluszek and her colleagues have demonstrated (Gluszek and Dovidio 2010a; Gluszek et al. 2011) perception of negative attitudes or prejudice towards a non-native accent can recoil, and lead to serious negative emotional consequences such as communication challenges and feeling less social belonging for the speaker.

When considering the role of accented speech in communication and social settings, one cannot overlook the question of comprehensibility. Indeed, it is possible that strong accents can be tolerated or even celebrated and slight accents may be subjected to prejudice and discrimination. Derwing and Munro stress that "accents do not cause discrimination - the fault is with intolerant, often monolingual interlocutors" (Derwing and Munro 2009: 485). It is the intergroup climate that is most responsible for the types of emotional dispositions that are generated for non-native accents.

The present study aims to connect the stigma of non-native accent to perceived L2 proficiency and L2 use anxiety. More particularly, we will argue that being stigmatized because of a non-native accent can undermine one's confidence with the second language, evoke anxiety and discourage communication.

\subsection{The conceptual model}

The conceptual model we test is built on the work of Clément and his associates (Clément et al. 2003) and integrates two perspectives of second language studies, the social context model of second language learning (Clément 1980; see also Clément et al. 2007; Sampasivam and Clément 2014) and the pyramid model 
of willingness to communicate in the second language (MacIntyre et al. 1998; see also MacIntyre 2007; MacIntyre et al. 2001).

Based on the tenets of the social context model (Clément 1980) and the convergent evidence from prior research (e.g. Clément 1986; Clément and Kruidenier 1985; Clément et al. 2003), we expect that frequent and pleasant contact with members of the second language group will increase L2 confidence. L2 confidence consists of a perception of competence to communicate in a second language and low levels of second language use anxiety (see e.g. Clément, Baker, Josephson and Noels 2005). Although higher levels of competence and lower levels of anxiety can be combined into a conglomerate of "selfconfidence," consistent with the approach taken in the pyramid model of WTC, we aim to assess the impact of contact on perceived L2 proficiency and L2 use anxiety separately. Specifically, we expect that frequent and pleasant contact with members of the second language group will increase perceived L2 proficiency and decrease L2 use anxiety.

Sampasivam and Clement (2014) argue that the relationship between perceived L2 proficiency and L2 use anxiety can vary according to the context (see also, Gardner and MacIntyre 1993). In bilingual settings, where the second language is present in the immediate environment, anxiety appears to be a more important predictor of communication in L2, whilst in monolingual settings, where language learners have little direct contact with speakers of the L2, perceived L2 proficiency more directly determines the willingness to communicate in L2. Perceived L2 proficiency and L2 use anxiety are constructs that interact with each other and their relationship is complex (MacIntyre 1995). Some research shows that anxiety arousal can bias the perception of L2 competence, such that anxious learners tend to underestimate their abilities (MacIntyre et al. 1997). However, when anxiety is defined as an emotional reaction to something gone wrong, or when it is aroused by anticipation of an inability to meet a future L2 challenge, it makes sense to treat anxiety as a consequence of perceived levels of L2 skills (e. g. Zhang 2000; Yim 2014). In line with this view, the present research treats perceived L2 proficiency as a precursor to L2 use anxiety.

In accordance with the studies reviewed above, we contend that whether the perception of high L2 proficiency results in relatively lower L2 use anxiety or not may depend on various factors. One of these factors is the feedback individuals receive from native speakers of L2 when communicating with them. In broad terms, feedback can be more or less supportive and may be related to various aspects of L2 communication (Marton and Vincze 2014). Clearly, positive feedback can reduce L2 use anxiety even in the case of the perception of low L2 proficiency, whereas negative feedback may make individuals more anxious also when they perceive themselves to be proficient in L2. Response to one's accent in L2, 
especially if it is negative, may be an important aspect of feedback. This line of thinking generates a key hypothesis to be tested in the present study: L2 speakers' feedback on the accent of their interlocutor can moderate the effect of perceived L2 proficiency on L2 use anxiety. Specifically, individuals who tend to receive more negative feedback on their accent from L2 speakers likely will be more anxious to use L2 even if they perceive themselves to be proficient in L2, whilst those who receive less negative feedback on their accent are likely to be less anxious even if their skills in L2 are lacking. Taken together, we expect that perceived L2 proficiency will be more closely related to L2 use anxiety in the case of little accent stigmatization than in the case of more accent stigmatization.

[Correction added after online publication 28 June 2016: Reference "(author, 2013)" was updated to "(Marton and Vincze 2014)" and the detailed reference was added to the reference list.]

Finally, as perceived L2 proficiency and L2 use anxiety are the most immediate predictors of willingness to communicate in L2 (MacIntyre et al. 1998; see also Clément et al. 2007), we anticipate that higher levels of perceived L2 proficiency and lower levels of L2 use anxiety will result in greater willingness to communicate in L2. The proposed model is depicted in Figure 1.

\subsection{The setting}

Giles et al. (1977) offered a framework for describing the strength, or ethnolinguistic vitality, of language groups along three dimensions: demography, status and institutional support (for a recent review, see Bourhis et al. 2012).

The Hungarian language group got into a minority position after the territory of the present Slovakia was torn from the Austro-Hungarian Empire as a result of the peace treaties following the World War I.

At the time of the 1921 census, ethnic Hungarians constituted 635,000 or $21 \%$ of the population. However, since that time, the size of the Slovak majority more than doubled, the number of ethnic Hungarians has been continuously shrinking (Kocsis and Hodosi 1998). The Hungarian minority has suffered the most substantial decrease in the last 20 years: while in 1991 there were 567,000 ethnic Hungarians in the country (10.8\%), in 2011 only 458,000 (8.5\%); this is a drop of almost $20 \%$, or 100,000 persons, during 20 years (Gyurgyík 2013).

The Hungarian language has no official status in Slovakia. Although the Act on the Use of Languages of National Minorities (2011) allows the use of Hungarian in settlements where the proportion of the Hungarian population 


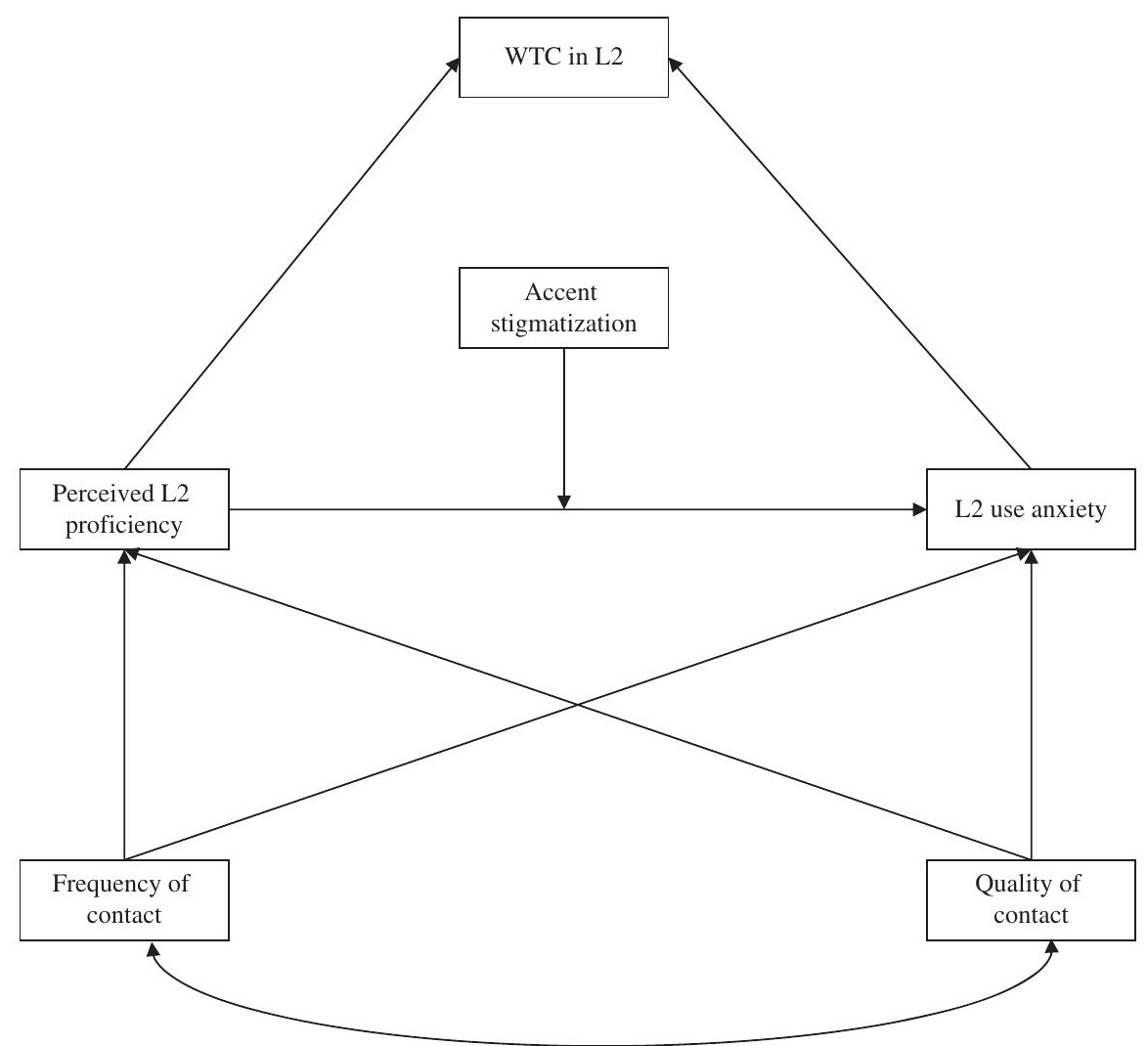

Figure 1: The conceptual model. The moderating effect (i. e., the interaction of accent stigmatization with perceived L2 proficiency) is depicted as an arrow from interaction of accent stigmatization to the path from perceived L2 proficiency to L2 use anxiety.

reaches $15 \%$, the State Language Act strictly sanctions any divergence from the use of Slovak. Notably, as it is stated in the Act on the Use of Languages of the National Minorities "The public administration body and employees thereof are not obligated to have command of the minority language." (Act on the Use of Minority Language, 1999/2011, Section 7, Paragraph 3). As a consequence, the official use of Hungarian is rather incidental and contradictory (e. g. Vass 2013).

There is a separate school system for the Hungarian minority, where the language of instruction is Hungarian. However, a quarter of Hungarian families regularly send their children to schools where the language of instruction is Slovak. In mixed language (i. e. Hungarian-Slovak) families this is the norm (Vincze 2010), and this tendency is seen usually as the most decisive factor in assimilation. The Slovak language is taught as a compulsory second language 
from first grade of primary school; in Slovak language schools it is not possible to learn Hungarian even as an optional subject.

Since 2004 the Hungarian minority has had a higher education institution, the Selye János University in the city of Komárom/Komárno. The university has three faculties (economy, education, and theology) and the language of instruction is Hungarian. Yet, a higher education degree is still far less common among ethnic Hungarians than among Slovaks. There is one Hungarian daily newspaper, "Új Szó”, and also Slovak public television and radio channels have a small amount Hungarian language programming (see Szabómihály 2003).

When it comes to intergroup relations, it is important to note that the relationship between Slovaks and Hungarians is burdened with several historical and political conflicts, which manifest not only with respect to the majorityminority context, but often also in the relationship between Slovakia and Hungary (e. g. Lanstyák and Szabómihály 2005, 2009).

All in all, the ethnolinguistic vitality of Hungarian can be considered low with respect to all three dimensions, and considerable assimilative tendencies are present.

\subsection{The Hungarian accent}

It is typical in both Hungarian and Slovak that stress is placed on the first syllable, therefore the two languages follow similar "rhythm". Although the phonetic system of Slovak and Hungarian overlap to a great extent, there are a few sounds in the Slovak language that are not found in Hungarian. In addition, while consonant clusters are not rare in Hungarian, more combinations of consonants occur in Slovak than in Hungarian, and it is sometimes difficult for Hungarian speakers to pronounce these. As Slovaks and Hungarians do not differ much in externally visible ways, the Hungarian accent is a salient factor that makes the ethnolinguistic boundary perceptible and defines who is "in" and who is "out".

Views on speaking Slovak with a Hungarian accent are rather negative within the Slovak majority and the Hungarian accent is typically stigmatized (Kontra 2013). This phenomenon is present at various layers of the society. For instance, in a debate in the national council of Slovakia, Anna Belousovová, a politician of the Slovak National Party criticised in her speech a politician of the Hungarian minority party because of his accent: "You are speaking with a terrible Hungarian accent; I was hardly able to translate some of your words” (Žemlová 2007).

The Hungarian accent is also often an object of humour in the mass media. The popular sitcom, Susedia (Neighbours) tells the story of two neighbouring couples, one of which is a Hungarian couple speaking with distinct Hungarian accent, which 
is the basis of many jokes (Nedelcu et al. 2010). However, Susedia is not the only TV show in which the Hungarian accent is mocked. As Kostovčík notes (2009: 178), "There are programs like SOS or Uragán, which build their humour on exaggerated archetypically-constructed characters in costume, with over-the-top accents mimicking the Hungarian or Roma language or various Slovak regional dialects, featuring in sketches with simple points, usually playing, again, on stereotypical traits of the social or cultural groups being mimicked” (Kostovčík 2009: 178).

The Hungarian accent is also a prevalent topic in everyday life. A present google search yields over 3,000 hits on the expression "Hungarian accent" in Slovak; and it appears to be a common topic in online discussion fora.

\subsection{The present study}

The present study is designed to test a model of the relationships among contact, anxiety, perceived L2 proficiency and WTC in the context of L1-Hungarian-speaking secondary school participants in Slovakia using the Slovak language as an L2. Our starting point is the theoretical model depicted in Figure 1, which proposes that more frequent and higher quality contact tends to be associated with lower L2 use anxiety and perceptions of higher L2 proficiency, in turn anxiety and perceive proficiency predict levels of WTC. In addition, we suggest that the relationship between anxiety and perceived L2 proficiency is expected to be significantly moderated by L1 (Hungarian) accent stigmatization.

\section{Method}

\subsection{Participants}

Self-report questionnaire data were collected in Hungarian secondary schools in November 2014 in Galánta/Galanta, Nagykapos/Velké Kapušany and Királyelmec/Královský Chlmec $(N=310) .62 \%$ of the respondents were boys, $38 \%$ girls. The average age of the participants was slightly less than 17 years $(M=16.71, S D=1.22)$.

\subsection{Measures}

Contact. The quality of contact was measured with six 5-point items (e. g. "My contact with Slovaks is usually enriching.") adapted from Clément and Baker 
(2001). The scale had a good reliability, $\alpha=0.84$. The frequency of contact was measured with three items based on Islam and Hewstone (1993); respondents were asked how much contact they had with Slovaks within their family and friends, how often they were engaged in informal conversations with Slovaks, and how often they visited the home of Slovaks. The reliability of the scale was good, $\alpha=0.83$. Higher values indicate more frequent contact and better quality of contact.

Perceived L2 proficiency. Respondents were asked to indicate on how they evaluate their proficiency on Slovak with respect to the four skills (speaking, listening, writing, and reading). A response format from 1 (poor) to 5 (excellent) was used. The measure had a good reliability, $\alpha=0.78$. Higher values indicate better proficiency.

L2 use anxiety. L2 use anxiety was measured with eight 5-point items (e. g. "When I make a telephone call, I get mixed up if I have to speak English") adapted from Clément and Baker (2001) and Gardner (2010). The compound scale had a good reliability, $\alpha=0.88$. Higher values indicate greater anxiety.

Accent stigmatization. Accent stigmatization was measured with five 5-point items from the accent stigmatization scale (Gluszek and Dovidio 2010). The scale included sample items such as "I think that in certain situations I am being discriminated against because I have an accent" and "I feel like an outsider because of my accent”. The measure had a good reliability, $\alpha=0.71$. Higher values indicate being more stigmatized by Slovaks because of a Hungarian accent.

Willingness to communicate in L2. Willingness to communicate was measured with seven 4-point items guided by MacIntyre et al. (2001). Respondents were asked to indicate how willing they would be to communicate in Slovak in certain situations (e.g. "Speaking in a group about your summer vacation", "With a German/Swedish speaking acquaintance while standing in line"). The scale had a good reliability, $\alpha=0.89$. Higher values indicate greater willingness to communicate in the L2.

\section{Results}

Table 1 includes means, standard deviations and correlations between the variables in the study. All correlations were statistically significant. Accent stigmatization was negatively related to both the frequency and quality of contact as well as to perceived L2 proficiency and willingness to communicate in the L2. As expected, however, accent stigmatization was positively related to L2 use anxiety. 
Table 1: Means, standard variations and intercorrelations between the variables in the study.

\begin{tabular}{|c|c|c|c|c|c|c|}
\hline & $\begin{array}{l}\text { Frequency } \\
\text { of contact }\end{array}$ & $\begin{array}{r}\text { Perceived L2 } \\
\text { proficiency }\end{array}$ & $\begin{array}{l}\mathrm{L} 2 \text { use } \\
\text { anxiety }\end{array}$ & $\begin{array}{r}\text { Accent } \\
\text { stigmatization }\end{array}$ & $\begin{array}{l}\text { WTC } \\
\text { in L2 }\end{array}$ & $\begin{array}{r}M \\
(S D)\end{array}$ \\
\hline Quality of contact & 0.52 & 0.45 & -0.60 & -0.45 & 0.62 & $\begin{array}{r}2.86 \\
(0.82)\end{array}$ \\
\hline Frequency of Contact & & 0.56 & -0.63 & -0.26 & 0.59 & $\begin{array}{r}2.50 \\
(0.97)\end{array}$ \\
\hline $\begin{array}{l}\text { Perceived L2 } \\
\text { proficiency }\end{array}$ & & & -0.67 & -0.22 & 0.56 & $\begin{array}{r}3.51 \\
(0.79)\end{array}$ \\
\hline L2 use anxiety & & & & 0.34 & -0.63 & $\begin{array}{r}3.29 \\
(0.92)\end{array}$ \\
\hline Accent stigmatization & & & & & -0.24 & $\begin{array}{r}2.98 \\
(0.83)\end{array}$ \\
\hline WTC in L2 & & & & & & $\begin{array}{r}2.48 \\
(0.69)\end{array}$ \\
\hline
\end{tabular}

Notes: All variables were measured on scales from 1 to 5 except for WTC, which was measured from a scale from 1 to 4 . Higher values indicate better quality of contact, more frequent contact, better perceived L2 proficiency, greater anxiety to use the L2, greater accent stigmatization and greater willingness to communicate in the L2. All relationships were significant at the $p<0.001$ level.

The proposed model was tested with path analysis using Mplus (Muthén and Muthén 1998-2015). When evaluating the fit of our model, we report absolute fit index (standardized root-mean-square residual; SRMR), a parsimony adjusted index (root-mean square error of approximation; RMSEA) and an incremental fit index (comparative fit index; CFI) in addition to chi-square test. As recommended by $\mathrm{Hu}$ and Bentler (1999), following criteria were applied as evidence of good fit: $\mathrm{CFI} \geq 0.95$, RMSEA $\leq 0.06, \mathrm{SRMR} \leq 0.08$. Variables which constituted the interaction terms were mean centred prior to the analysis.

The initial model produced unacceptable fit, $\chi^{2}(6)=73.82, p<0.001$, RMSEA $=0.19, \mathrm{CFI}=0.89, \mathrm{SRMR}=0.11$. Modification indices suggested adding a path between quality of contact and accent stigmatization. As this path was consistent with our theoretical view (i. e. that lower quality of contact might be related to a higher degree of perceived accent stigmatization, see e. g. Derwing and Munro 2009), it was added to the model. Following this modification, the final model fit the data well, $\chi^{2}(3)=4.80, p=0.19$, RMSEA $=0.04, \mathrm{CFI}=1.00$, $\mathrm{SRMR}=0.01$, and accounted for $54 \%$ of the variance in willingness to communicate in the L2, 35\% of the variance in perceived L2 proficiency and $61 \%$ of the variance in L2 use anxiety. The results are summarized in Figure 2. As expected, frequency and quality of contact were positively related to perceived L2 


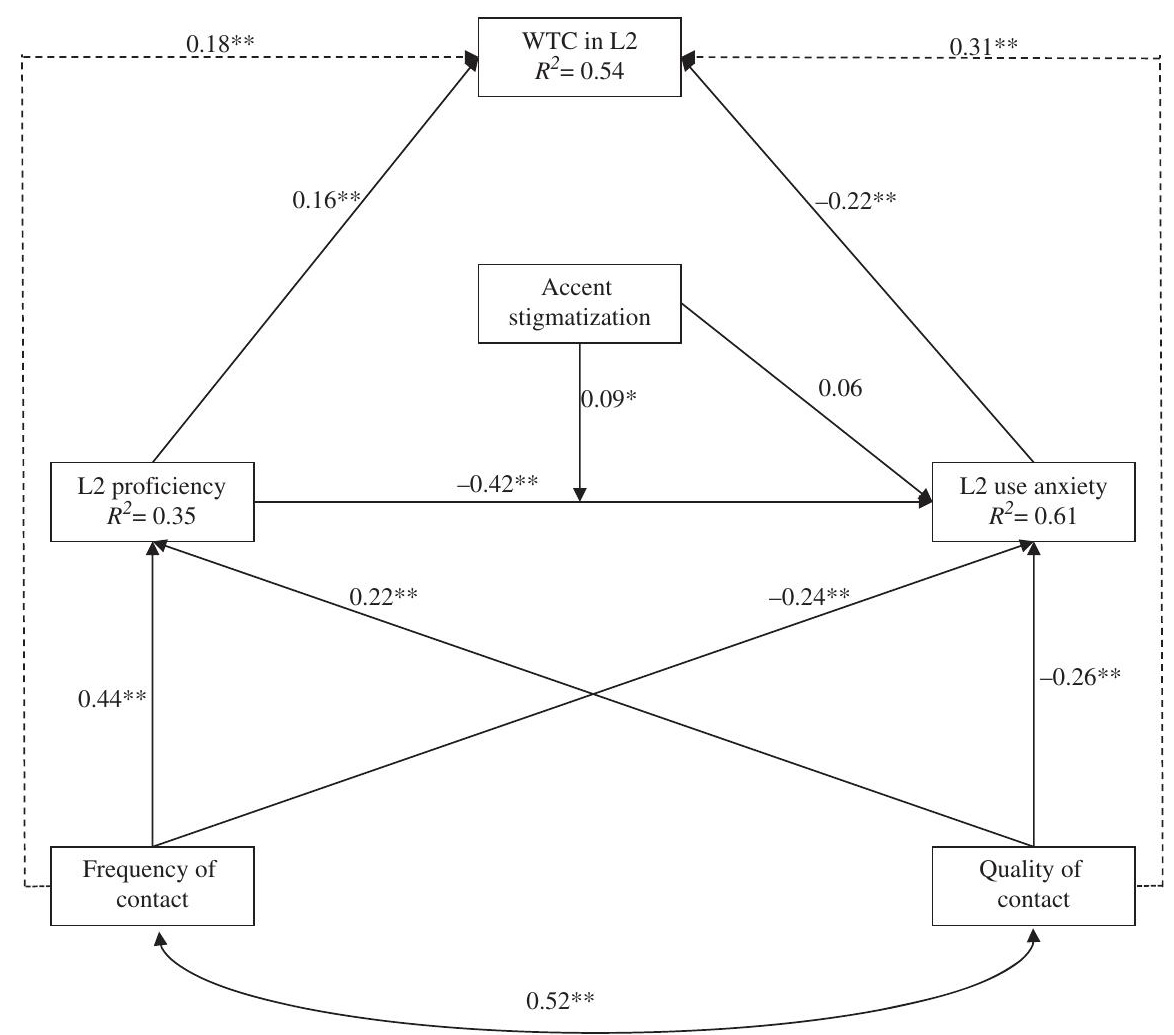

Figure 2: Results of the path analysis. The figure shows standardized coefficients. In addition, quality of contact was significantly related to accent stigmatization $(\beta=-0.45, p<0.01)$. This path is not shown in the figure for the sake of clarity.

proficiency and negatively related to L2 use anxiety, while perceived L2 proficiency was positively and L2 use anxiety was negatively related to willingness to communicate in the L2. In addition, and supportive of the novel hypothesis being tested in the model, we found that the relation between perceived L2 proficiency and L2 use anxiety was significantly moderated by accent stigmatization.

The interaction was decomposed with the PROCESS macro (Hayes 2013). In order to be able to present standardized coefficients, variables which constituted the interactions terms were standardized prior to the analysis. Quality and frequency were added as covariates. The simple slopes are depicted in Figure 3. As anticipated, perceived L2 proficiency was more closely related to L2 use anxiety in the case of little accent stigmatization $(\beta=0.58, p<0.001)$ than 


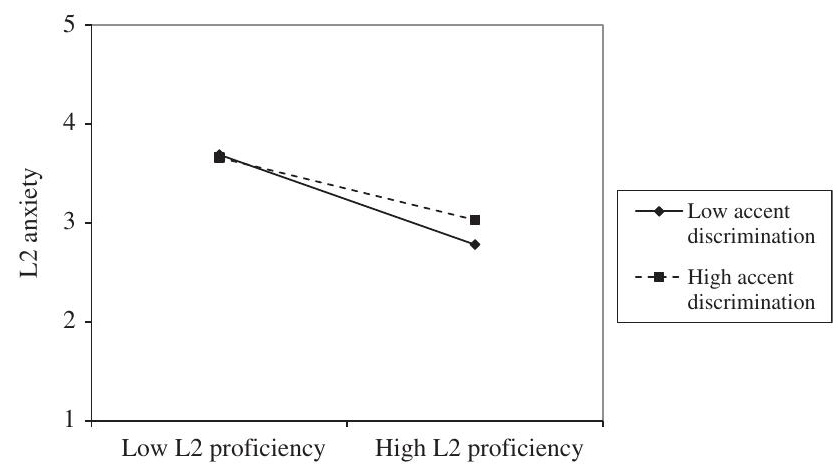

Figure 3: Predicted values of $L 2$ use anxiety based on perceived $L 2$ proficiency and perceived accent stigmatization.

in the case of more accent stigmatization ( $\beta=0.40, p<0.001)$. Additionally, it can also be seen that accent stigmatization affects anxiety more strongly among those participants who perceived their L2 skills to be good.

Although our focus was on examining how accent stigmatization moderates the effect of perceived L2 proficiency on L2 use anxiety, we are aware that it is possible to consider the effect of anxiety on perceptions of competence. We performed a further analysis to test the path in the reverse direction, that is, whether accent stigmatization moderates the effect of L2 use anxiety on perceived L2 proficiency. In this case, the interaction term was not significant, $\beta=-0.06, p=0.12$, indicating the lack of a moderating effect. The analysis showed that perceived L2 proficiency was predicted by L2 use anxiety, $\beta=-0.39, p<0.01$, but not by accent stigmatization $\beta=0.01, p=0.74$.

\section{Discussion}

By integrating the social context model of L2 acquisition with the pyramid model of willingness to communicate in L2 (see Clément et al. 2003), the present study describes how contact with Slovaks contributes to perceived proficiency in Slovak and anxiety about speaking Slovak, as well as how these predict willingness to communicate in Slovak among young Hungarian speakers in Southern Slovakia. Of particular interest is the role that perception of accent stigmatization plays in the above process. To be more specific, we found evidenced that accent stigmatization can moderate the relationship between perceived proficiency in Slovak and anxiety about speaking Slovak. 
Supporting our expectations and in line with previous empirical findings (e. g. Clément et al. 2003; Clément and Kruidenier 1985; MacIntyre et al. 2001), the results indicated that frequent and pleasant contact with Slovak speakers was related to higher proficiency in Slovak and lower anxiety to use Slovak, and these increased the willingness to communicate in Slovak.

Also, it was demonstrated that accent stigmatization moderated the relationship between perceived L2 proficiency and L2 use anxiety. Among those participants who were less stigmatized because of having a non-native accent, L2 use anxiety was more closely associated with perceived L2 proficiency than among those who were more stigmatized because of having a non-native accent. In particular, Figure 3 shows that the anxiety-provoking effect of accent stigmatization is most prevalent among those who otherwise evaluated their L2 proficiency to be good, while those who perceived having poorer skills in the L2 accent stigmatization did not lead to as much of an increase in anxiety. One possible explanation for this phenomenon might be that pronunciation issues may be most relevant in case of advanced L2 skills. In other words, those individuals who evaluated their L2 proficiency to be high perhaps have relatively little difficulty with more fundamental issues of the L2 (such as grammar or vocabulary) when communicating to L2 speakers. At the same time, those individuals who evaluated their L2 proficiency to be low may attribute their anxiety to difficulties with grammar or vocabulary, and not because of pronunciation related issues. Among speakers with higher self-rated L2 ability, despite their efforts at learning, accent stigmatization might serve to highlight their barriers to success, rather than progress, in communicating in the L2. Among those respondents who see themselves as having developed L2 skills, the presence of accent stigmatization predicts higher levels of L2 use anxiety.

The findings of this study are novel and have important theoretical and practical implications. With respect to theoretical implications, it is noteworthy that prior research into the stigma of non-native accent has focused mostly on the role of perception of accent stigmatization in communication challenges and lack of social belonging (Gluszek and Dovidio 2010; Gluszek et al. 2011). The present data demonstrates the role of accent stigmatization in the development of L2 use anxiety in a bilingual environment, and we integrated the role of accent perception into a broader model of L2 communication. Also, whereas studies addressing the sources of L2 use anxiety revealed the role of factors such as the educational context, personality and emotional intelligence (for a review, see Horwitz 2010), there has been only indirect evidence thus far on specific ways in which the social context might promote L2 use anxiety (Gardner and MacIntyre 1993; Sampasivam and Clement 2014). The present paper has 
highlighted accent stigmatization as a specific feature of the intergroup context that can contribute to the development of L2 use anxiety.

The findings of this study also have practical implications. In the present social context, speaking Slovak with a Hungarian accent is relevant not only to particular individuals but also at the societal level in domains such as politics and mass media (Kontra 2013; Kostovčík 2009; Nedelcu et al. 2010; Žemlová 2007). In general, it is unlikely that this set of circumstances either aids or facilitates mutual understanding, respect and acceptance between the language groups in any society, but it is especially true in the context of the present study. Great differences in power relations between the language groups as well as in the vitalities of the languages, and the fact that Slovaks are not taught Hungarian as an L2, appear to encumber intergroup communication; there is a noticeable imbalance. As a consequence, accent stigmatization may sully everyday interactions between language groups, make intergroup communication even more unbalanced, and contribute to maintaining and reproducing minority-majority status differences and further entrench power relations. It is especially remarkable, and somewhat ironic, that accent stigmatization was associated with more anxiety among those participants who otherwise evaluated their skills in Slovak to be good. Certainly, in a context like this, local language policy would do well to address the issue of accent stigmatization to promote greater tolerance and better relations between the language groups.

The present study has several limitations. We collected the data using a convenience sample, with a young age group, in a cross-sectional research design. Our analytic approach used structural equation modelling procedures to test the theoretical model; other data analytic approaches including longitudinal, qualitative, dynamic and person-oriented methods such as cluster analysis could provide additional insight into the effects of accent stigmatization. Furthermore, although we structured our model in accordance with a specific theoretical perspective, we are aware that other theoretical approaches are possible, and alternative relations among the variables could be specified. For instance, accent stigmatization may be conceived both as a predictor of perceived L2 proficiency (that is, implanted in the perception of one's own L2 skills) and a moderator between perceived L2 proficiency and L2 use anxiety. Further, perceived L2 proficiency, accent stigmatization and anxiety can contribute not only to willingness to communicate but also to the quality of contact with L2 speakers. Although accent stigmatization proved to be a fairly strong negative correlate of contact quality, the specific theoretical model that can account for such a correlation is open for debate. 
Nevertheless, shortcomings aside, the present study provides new evidence of the relevance and importance of accent stigmatization in intergroup communication, and its potential relation to L2 use anxiety. Future research might choose to attempt to replicate these findings in other bilingual contexts with different power relations between groups. Furthermore, future research could also examine individuals and use a person-oriented analysis to identify common profiles of accent stigmatization, L2 use anxiety and willingness to communicate in the L2. Finally, a fruitful avenue of future research could be to examine native speakers' evaluation of non-native speakers' accent strength and also their attitudes towards interlocutors with non-native accents.

Funding: Ella and Georg Ehrnrooth Foundation, Helsinki and Finnish Cultural Foundation, Helsinki.

\section{References}

Act on the Use of Languages of National Minorities. 2011. Act No. 204/2011 Col. L. amending Act No. 184/1999 Col. L. on the Use of Minority Languages. http://www.ucps.sk/Zakon_184_ 1999_0_pouzivani_jazykov_narodnostnych_mensin (accessed 20 February 2016).

Bourhis, Richard Y., Rana Sioufi \& Itesh Sachdev. 2012. Ethnolinguistic interaction and multilingual communication. In Howard Giles (ed.), The handbook of intergroup communication, 100-115. New York: Routledge.

Clément, Richard. 1980. Ethnicity, contact and communicative competence in a second language. In Howard Giles, Peter W. Robinson \& Philip M. Smith (eds.), Language: Social psychological perspectives, 147-154. Oxford, UK: Pergamon.

Clément, Richard. 1986. Second language proficiency and acculturation: An investigation of the effects of language status and individual characteristics. Journal of Language and Social Psychology 5(4). 271-290.

Clément, Richard \& Susan C. Baker. 2001. Measuring social aspects of L2 acquisition and use: Scale characteristics and administration. Ottawa: University of Ottawa, School of Psychology.

Clément, Richard, Susan C. Baker \& Peter D. MacIntyre. 2003. Willingness to communicate in a second language. The effects of context, norms, and vitality. Journal of Language and Social Psychology 22(2). 190-209.

Clément, Richard, Susan C. Baker, Gordon Josephson \& Kim A. Noels. 2005. Media effects on ethnic identity among linguistic majorities and minorities: A longitudinal study of a bilingual setting. Human Communication Research 31(3). 399-422.

Clément, Richard \& Bastian G. Kruidenier. 1985. Aptitude, attitude and motivation in second language proficiency: A test of Clément's model. Journal of Language and Social Psychology 4(1). 21-37.

Clément, Richard, Kimberly A. Noels \& Peter D. Maclntyre. 2007. Three variations on the social psychology of bilinguality: Context effects in motivation, usage and identity. In Ann 
Weatherall, Bernadette Watson \& Cindy Gallois (eds.), Language, discourse and social psychology, 51-77. Melbourne, Australia: Palgrave MacMillan.

Derwing, Tracey M. \& Murray J. Munro. 2009. Putting accent in its place: Rethinking obstacles to communication. Language Teaching 42(4). 476-490.

Derwing, Tracey M. 2003. What do ESL students say about their accents? Canadian Modern Language Review 59. 547-566.

Dewaele, Jean-Marc. 2002. Psychological and sociodemographic correlates of communicative anxiety in L2 and L3 production. The International Journal of Bilingualism 6(1). 23-39.

Dewaele, Jean-Marc. 2013. The link between foreign language classroom anxiety and psychoticism. Extraversion and neuroticism among adult bi- and multilinguals. The Modern Language Journal 97(3). 670-684.

Dewaele, Jean-Marc, K. V. Petrides \& Adriann Furnham. 2008. Effects of trait emotional intelligence and sociobiographical variables on communicative anxiety and foreign language anxiety among adult multilinguals: A review and empirical investigation. Language Learning 58(4). 911-960.

Fuertes, Jairo. N., William Gottdiener, Helena Martin, Tracey C. Gilbert \& Howard Giles. 2012. A meta-analysis of the effects of speakers' accents on interpersonal evaluations. European Journal of Social Psychology 42(1). 120-133.

Gardner, Robert C. 2010. Motivation and second language acquisition: The socio-educational model. New York/Berlin: Peter Lang.

Gardner, Robert C. \& Peter D. Maclntyre. 1993. A student's contributions to second-language learning. Part II: Affective variables. Language teaching 26(1). 1-11.

Giles Howard, Richard Y. Bourhis \& Don Taylor. 1977. Towards a theory of language in ethnic group relations. In Howard Giles (ed.), Language, ethnicity and intergroup relations, 307-348. New York: Academic Press.

Gluszek, Agata \& John F. Dovidio. 2010a. Speaking with a nonnative accent: Perceptions of bias, communication difficulties, and belonging in the United States. Journal of Language and Social Psychology 29(2). 224-234.

Gluszek, Agata \& John F. Dovidio. 2010b. The way they speak: A social psychological perspective on the stigma of non-native accents in communication. Personality and Social Psychology Review 14. 214-237.

Gluszek, Agata, Anna-Kaisa Newheiser \& John F. Dovidio. 2011. Social psychological orientations and accent strength. Journal of Language and Social Psychology 30(1). 28-45.

Gregersen, Tammy S. \& Elaine K. Horwitz. 2002. Language learning and perfectionism: Anxious and non-anxious language learners' reactions to their own oral performance. The Modern Language Journal 86(4). 562-570.

Gregersen, Tammy \& Peter MacIntyre. 2014. Capitalizing on language learners' individuality: From premise to practice. Clevedon: Multilingual Matters.

Gyurgyík, László. 2013. A szlovákiai magyarság demográfiai folyamatai 1989-től 2011-ig. [Demographic processes among the Hungarian minority in Slovakia between 1989 and 2011]. Somorja/Šamorín, Slovakia: Fórum Kisebbségkutató Intézet.

Hayes, Andrew. F. 2013. Introduction to mediation, moderation, and conditional process analysis: A regression-based approach. New York: Guilford.

Horwitz, Elaine K. 2001. Language anxiety and achievement. Annual Review of Applied Linguistics 21. 112-126.

Horwitz, Elaine K. 2010. Foreign and second language anxiety. Language Teaching 43(2). 154-167. 
Hu, Li-tze \& Peter M. Bentler. 1999. Cutoff criteria for fit indexes in covariance structure analysis: conventional criteria versus new alternatives. Structural Equation Modeling: A Multidisciplinary Journal 6. 1-55.

Islam, Mir Rabiul \& Miles Hewstone. 1993. Dimensions of contact as predictors of intergroup anxiety, perceived out-group variability, and out-group attitude: An integrative model. Personality and Social Psychology Bulletin 19(6). 700-710.

Kocsis, Károly \& Eszter Hodosi. 1998. Ethnic geography of the Hungarian minorities in the Carpathian basin. Budapest: Hungarian Academy of Sciences.

Kontra, Miklós. 2013. Magyar kétnyelvüség - áldás vagy átok? [Hungarian Bilingualism a Curse or a Blessing?]. Papers of Hungarian Studies 14(3). 1-11.

Kostovčík, Lukáš. 2009. The translation of verbally-expressed humor on screen in Slovakia: An outline of research problems. In Milan Ferenčík \& Juraj Horvath (eds.), Language, literature and culture in a changing translantic world, 175-180. Prešov, Slovakia: University of Prešov.

Lambert, Wallace E. 1967. A social psychology of bilingualism. Journal of Social Issues 23(2). 91-109.

Lanstyák, István \& Gizella Szabómihály. 2005. Hungarian in Slovakia. In Anna Fenyvesi (ed.), Hungarian language contact outside hungary, 47-88. Amsterdam: John Benjamins.

Lanstyák, István \& Gizella Szabómihály. 2009. Hungarian in Slovakia: Language management in a bilingual minority community. In Jiři Nekvapil \& Tamah Sherman (eds.), Language management in contact situations, 75-98. Frankfurt: Internationaler Verlag der Wissenschaften.

MacIntyre, Peter D. 1995. How does anxiety affect second language learning? A reply to Sparks and Ganschow. The Modern Language Journal 79(1). 90-99.

Maclntyre, Peter D. 1999. Language anxiety: A review of the research for language teachers. In Dolly J. Young (ed.), Affect in foreign language and second language teaching: A practical guide to creating a low-anxiety classroom atmosphere, 24-45. Boston: McGraw-Hill.

MacIntyre, Peter D. 2007. Willingness to communicate in the second language: Understanding the decision to speak as a volitional process. Modern Language Journal 91(4). 564-576.

MacIntyre, Peter D., Kimberly A. Noels \& Richard Clément. 1997. Biases in self-ratings of second language proficiency: The role of language anxiety. Language Learning 47(2). 265-287.

MacIntyre, Peter. D., Zoltán Dörnyei, Richard Clément \& Kimberly A. Noels. 1998. Conceptualizing willingness to communicate in a L2: A situational model of L2 confidence and affiliation. The Modern Language Journal 82(4). 545-562.

MacIntyre, Peter D., Susan C. Baker, Richard Clément \& Sarah Conrod. 2001. Willingness to communicate, social support, and language-learning orientations of immersion students. Studies in Second Language Acquisition 23(3). 369-288.

Marton, Enikő \& László Vincze. 2014. Hur öka användningen av svenska hos finskspråkiga? [How to increase the use of Swedish among Finnish speakers?] Språkbruk 4. 26-28.

Munro, Murray, J. 2003. A primer on accent discrimination in the Canadian context. TESL Canada Journal 20(2). 38-51.

Muthén, Linda K. \& Bengt O. Muthén. 1998-2012. Mplus user's guide, 7th edn. Los Angeles: Muthén \& Muthén.

Nedelcu, Anca, Romita lucu \& Lucian Ciolan. 2010. Students' perception of the "others" in ethnic separated school systems. European Education 42(4). 69-86.

$\mathrm{Ng}$, Sik Hung. 2007. Language-based discrimination: Blatant and subtle forms. Journal of Language and Social Psychology 26(2). 106-122. 
Sampasivam, Sinthujaa \& Richard Clément. 2014. The dynamics of second language confidence: Perspective and interaction. In Sarah Mercer \& Marion Williams (eds.), Multiple perspectives on the self in SLA, 23-40. Bristol: Multilingual Matters.

Soliz, Jordan \& Howard Giles. 2014. Relational and identity processes in communication: A contextual and meta-analytical review of Communication Accommodation Theory. Communication Yearbook 38. 106-143.

Szabómihály Gizella. 2003. A szlovákiai kisebbségek nyelvi jogai és a kisebbségi nyelvhasználat színterei, különös tekintettel a magyar közösségre. [Language rights of the minorities in Slovakia with special regard to the Hungarian community]. In 0. Nádor \& L. Szarka (eds.), Nyelvi jogok, kisebbségek, nyelvpolitika Kelet-Közép-Európában [Language rights, minorities, language policies in Eastern-Central-Europe], 95-109. Budapest: Akadémiai Kiadó.

Vass, Ágnes. 2013. Miért nem lehet, ha szabad? [Why is it not possible even when it is allowed?]. Pro Minoritate 23(4). 42-59.

Vincze, László. 2010. Zur Schulwahl und Identität unter der ungarischen Minderheit in der Slowakei [Choice of school and identity among the Hungarian minority in Slovakia]. Europa Ethnica - Zeitschrift für Minderheitenfragen 67(2). 29-34.

Zhang, Lawrence Jun. 2000. Uncovering Chinese ESL students' reading anxiety in a studyabroad context. Asia Pacific Journal of Language in Education 3(2). 31-56.

Žemlová, Monika. 2007, October 27. Belousovová: Máte hrozný mad’arský prízvuk. [Belousovová: You have a terrible Hungarian accent]. Sme. http://www.sme.sk/c/3557359/ belousovova-mate-hrozny-madarsky-prizvuk.html (accessed 20 February 2016).

Yim, Su Yon. 2014. An anxiety model for EFL young learners: A path analysis. System 42(1). 344-354.

[Correction added after online publication 28 June 2016: Reference "Marton, Enikő and László Vincze. 2014. Hur öka användningen av svenska hos finskspråkiga? [How to increase the use of Swedish among Finnish speakers?] Språkbruk, 4, 26-28" was added to the reference list.] 